\title{
Outdoor human thermal comfort in local climate zones of Novi Sad (Serbia) during heat wave period
}

\author{
Dragan D. MiLOŠEVIĆ ${ }^{1}$, SteVAn M. SAVIĆ ${ }^{,}$, Vladimir MARKOVIĆ ${ }^{2}$ \\ DANIELA ARSENOVIĆ ${ }^{2}$ and IVAN ŠEĆEROV ${ }^{3}$
}

\begin{abstract}
Urban climate monitoring system (UCMS) was established in Novi Sad (Serbia) in 2014 based on the Local Climate Zones (LCZs) classification system, GIS model calculations and field work. Seven built and two land cover LCZ types were delineated and 27 stations equipped with air temperature and relative humidity sensors were distributed across all LCZs. Suitability of the developed monitoring system for human outdoor thermal comfort research in different LCZs of the city and its surroundings was investigated during a heat wave period using Physiologically Equivalent Temperature (PET) index. During the daytime (night-time) the highest thermal loads are present in open midrise (compact midrise) LCZ, while the most comfortable is LCZ A (dense trees) during the whole day. In general, the highest thermal loads are obtained in midrise, followed by low-rise, sparsely built, low plants and dense trees LCZs. All LCZs (except LCZ A - dense trees) had higher PET when compared to LCZ D (LCZ D - low plants) during evening and nocturnal hours with maximum difference of $7.1^{\circ} \mathrm{C}$ (00 UTC) between LCZ 2 (compact midrise) and LCZ D (low plants). Contrary to this, LCZ D (low plants) had higher PET compared to the majority of LCZs during the daytime with maximum difference of $8.5^{\circ} \mathrm{C}(9$ UTC) when compared to LCZ A (dense trees). Furthermore, the smallest thermal comfort differences during heat wave occurred between LCZs with similar structure (i.e. open low-rise and large low-rise, compact midrise and compact low-rise) and cover (i.e. sparsely built and low plants).
\end{abstract}

Keywords: urban climate monitoring, local climate zone, thermal comfort, heat wave, Novi Sad, Serbia

\section{Introduction}

People living in urban areas are under substantial thermal stress during the extreme temperature events such as heat wave (HW). Thermal discomfort will be exaggerated in the future as climate change scenarios show increase in the intensity and frequency of HWs in Europe in the twenty first century (Christensen, J. et al. 2007). Thus, monitoring of outdoor human thermal comfort conditions will provide important data for urban planners and decision-makers in order to create lively urban areas for its residents in the future (MilošEvić, D.D. et al. 2015a).
Development of urban climate monitoring system (UCMS) is needed in order to comprehensively investigate outdoor human thermal comfort in urban areas. Two UCMSs were developed in Novi Sad (Serbia) and Szeged (Hungary) in 2014 as part of the EU-founded research (URBAN-PATH, http://urban-path. hu) (UNGER, J. et al. 2014). The networks were planned and based on the local climate zone classification system scheme developed by STEWART, I.D. and OKe, T.R. (2012). LCZs are defined as "regions of uniform surface cover, structure, material, and human activity that span hundreds of metres to several kilometres in horizontal scale" (Stewart, I.D. and OKE,

\footnotetext{
${ }^{1}$ Climatology and Hydrology Research Centre, Faculty of Sciences, University of Novi Sad, Trg Dositeja Obradovića 3, 21000 Novi Sad, Serbia. E-mails: dragan.milosevic@dgt.uns.ac.rs, stevan.savic@dgt.uns.ac.rs

${ }^{2}$ Center for Spatial Information of Vojvodina Province, Faculty of Sciences, University of Novi Sad; Trg Dositeja Obradovića 3, 21000 Novi Sad, Serbia. E-mails: vladimir.markovic@dgt.uns.ac.rs; daniela.arsenovic@dgt.uns.ac.rs

${ }^{3}$ Department of Geography, Tourism and Hotel Management, Faculty of Sciences, University of Novi Sad, Trg Dositeja Obradovića 3, 21000 Novi Sad, Serbia.
} 
T.R. 2012). LCZ mapping method by LeLoviCs, E. et al. (2014), local urban climate knowledge and field work were needed in the process of delineation of LCZs in Novi Sad and the selection of suitable sites for the meteorological sensors deployment. Seven built and two land cover LCZ types were delineated in Novi Sad and air temperature ( $\mathrm{Ta}$ ) and relative humidity $(R H)$ sensors were deployed on 27 locations inside them (UnGER, J. et al. 2014). URBAN-PATH Portal and Urban Path System tool (UP-SYS tool) were created in order to visualise, process and save measured data for urban climate studies and for analysing entire systems work (ŠEĆEROv, I. et al. 2015).

To further improve the LCZ system, STEWART, I.D. et al. (2014) encouraged researchers to observe the climatic conditions of different LCZs. Recently, evaluation of LCZ scheme using stationary and (or) mobile measurements was performed in Glasgow (United Kingdom) (EMmanueL, R. and Krüger, E. 2012), Hong Kong SAR (China) (Siu, L.W. and Hart, M.A. 2013), Mendoza (Argentina) (Puliafito, S. et al. 2013), Dublin (Ireland) (Alexander, P.J. and Mills, G. 2014), Berlin (Germany) (Fenner, D. et al. 2014), Oberhausen (Germany) (Muller, N. et al. 2014), Olomouc (Czech Republic) (Lehnert, M. et al. 2014), Barranquilla (Colombia) (Villadiego, K. and Velay-Dabat, M.A. 2014), Kochi (India) (Thomas, G. et al. 2014), Nagano (Japan), Vancouver (Canada) and Uppsala (Sweden) (Stewart, I.D. et al. 2014) as well as Nancy (France) (Leconte, F. et al. 2015), Novi Sad (Serbia) (Unger, J. et al. 2011; SAvić, S. et al. 2013; MilošEvić, D.D. et al. 2015a,b; SAvić, S. et al. 2015), Dar es Salaam (Tanzania) (Ndetto, E.L. and Matzarakis, A. 2015) and Szeged (Hungary) (UNGER, J. et al. 2015; Lelovics, E. et al. 2016). Nevertheless, further evaluations of conceptual division of urban-rural landscape into LCZs with meteorological and climatologic data as well as numerical models are needed. Obtained results will highlight necessary changes to the LCZ classification system needed to more accurately classify urban thermal environments (StewART, I.D. et al. 2014).
In this study, we analyse the outdoor human thermal comfort conditions in different LCZs of the city of Novi Sad (Serbia). Results and conclusions will provide insight into outdoor comfort conditions in different LCZs of the city and reveal whether the urban climate monitoring network based on LCZ scheme is suitable for the intra-urban thermal comfort research. Temporary analysis was performed using weather data from extreme temperature event (HW).

\section{Materials and methods}

Novi Sad is a mid-sized city in the northern part of the Republic of Serbia (Southeast Europe), located on a plain from 80 to $86 \mathrm{~m}$ a.s.l. $\left(45^{\circ} 15^{\prime} \mathrm{N}, 19^{\circ} 50^{\prime} \mathrm{E}\right)$. The river Danube flows along the southern and the south-eastern edge of the city, and its width varies from 260 to $680 \mathrm{~m}$. The relatively narrow DanubeTisza-Danube Canal passes through the northern part of the city (Figure 1). To the South of Novi Sad urban area, the northern slopes of Fruška Gora Mountain are located (the highest peak is $538 \mathrm{~m}$ a.s.1.) which descend steeply towards the Danube (Unger, J. et al. 2011). Novi Sad is the second largest city in Serbia with a population of 340,000 (BAJŠANSKI, I.V. et al. 2015) and built-up area of $112 \mathrm{~km}^{2}$.

The area is in Köppen-Geiger climate region $C f b$ (temperate warm climate with a rather uniform annual distribution of precipitation) (Коттек, M. et al. 2006). The mean annual air temperature in Novi Sad is $11.2^{\circ} \mathrm{C}$ with an annual range of $22.1^{\circ} \mathrm{C}$. The coldest month is January $\left(-0.4^{\circ} \mathrm{C}\right)$ and the warmest month is July $\left(21.7^{\circ} \mathrm{C}\right)$. The mean annual amount of precipitation is $598 \mathrm{~mm}$ (based on the data from 1949 to 2013) (BAJŠANSKI, I.V. et al. 2015).

For the determination of outdoor human thermal comfort conditions in different LCZs during a HW period (from $5^{\text {th }}$ to $8^{\text {th }}$ July 2014), PET index (Table 1) was calculated in RayMan model (Matzarakis, A. et al. 2007). Selected days were characterized by prevailing anticyclonic conditions. 


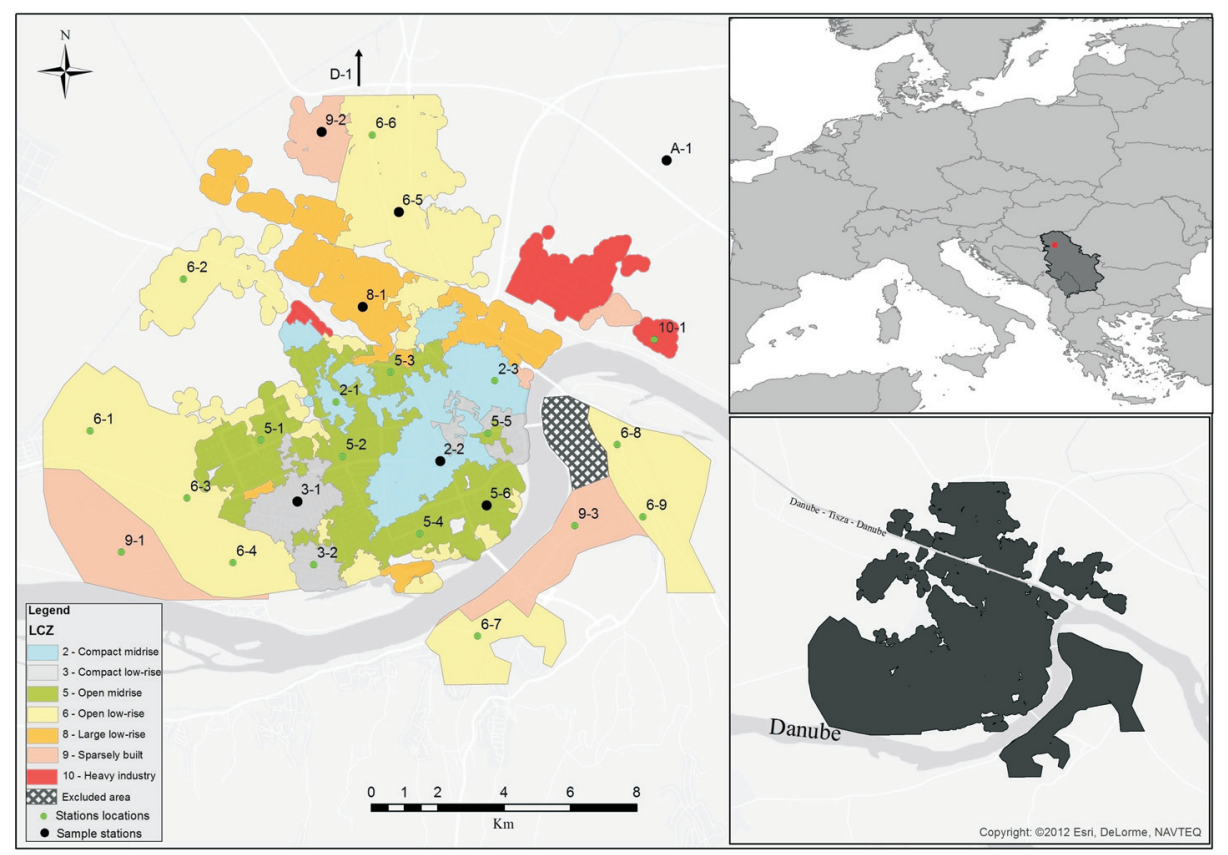

Fig. 1. Location of Novi Sad in Europe and Serbia (the red square upper right) and its built-up area (down right) as well as LCZs and stations sites (left; black dots = investigated sites). First number = LCZ class number, second number = station's identity number in the given LCZ class

Table 1. PET index threshold values for thermal sensation and the physiological

\begin{tabular}{|c|c|c|}
\hline $\mathrm{PET},{ }^{\circ} \mathrm{C}$ & Thermal sensation & $\begin{array}{c}\text { Physiological stress } \\
\text { level }\end{array}$ \\
\hline under 4 & Very cold & Extreme cold stress \\
\hline $4-8$ & Cold & Strong cold stress \\
\hline $8-13$ & Cool & Moderate cool stress \\
\hline $13-18$ & Slightly cool & Slight cold stress \\
\hline $18-23$ & Comfortable & No thermal stress \\
\hline $23-29$ & Slightly warm & Slight heat stress \\
\hline $29-35$ & Warm & Moderate heat stress \\
\hline $35-41$ & Hot & Strong heat stress \\
\hline over 41 & Very hot & Extreme heat stress \\
\hline
\end{tabular}

*After Matzarakis, A. and Mayer, H. 1996.

The input data for the calculation of PET are hourly air temperature $(T a)$, relative humidity $(R H)$, wind speed $(v)$ and global radiation fluxes $(g)$ for selected days. The $\mathrm{Ta}$ and $\mathrm{RH}$ are measured by the stations network, while the $v$ for Novi Sad are from daily WRF model (Michalakes, J. et al. 2004) predictions initiated at 0 UTC for the Pannonian Basin using and NOAA/NCEP global forecast (GFS) (EMC 2003). The $v$ was corrected using the roughness length calculated by the Roughness Mapping Tool (GÁL, T. and Unger, J. 2009). RayMan model was used for the calculation of $g$. Time is given in Universal Time Coordinated (UTC). Local Standard Time in Serbia during summer is $\mathrm{UTC}+2 \mathrm{~h}$ (Central European Summer Time). Representative station (Figure 2) for each LCZ was selected and their urban environment was modelled in RayMan model. The excep- 


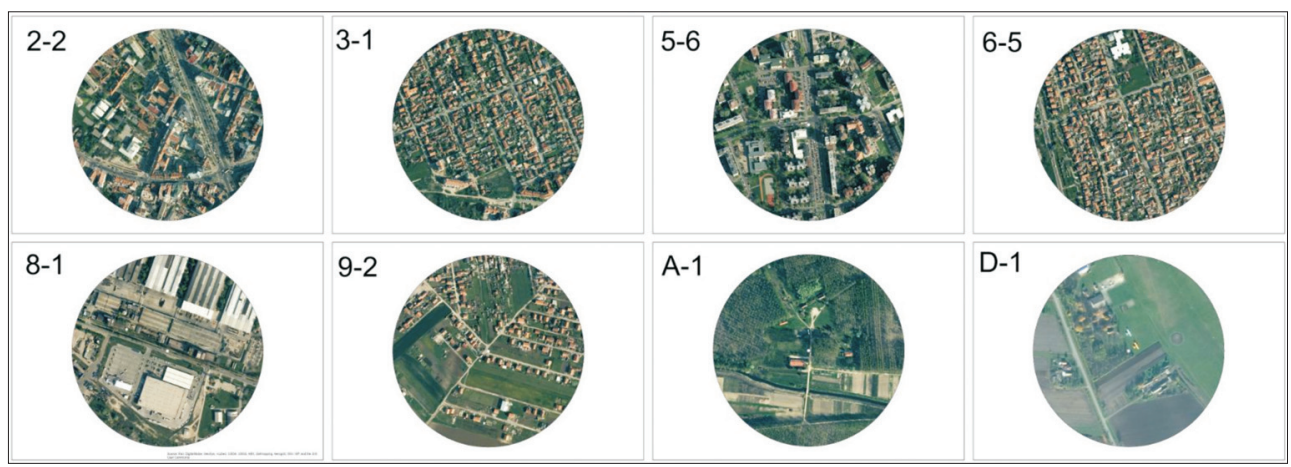

Fig. 2. Aerial photographs illustrating selected measurement sites (in the middle of the photo) with an environment of $500 \mathrm{~m}$ diameter in Novi Sad. First number = LCZ class number, second number = station's identity number in the given LCZ class: 2-2 (compact midrise), 3-1 (compact low-rise), 5-6 (open midrise), 6-5 (open low-rise), 8-1 (large low-rise), 9-2 (sparsely built), A-1 (dense trees), D-1 (low plants)

tion is station 10-1 (heavy industry) that did not work in the analysed period and could not be part of the analysis.

Several methods were applied in order to assess the statistical significance of average hourly PET differences between LCZs for whole HW as well as for daytime (from 4 UTC to 18 UTC) and night-time period (from 19 UTC to 3 UTC).

Firstly, hourly PET values in LCZ (PET $x$ ) were used to calculate average hourly PET values in individual LCZ for the whole HW period $(\overline{P E T} x, i)$.

Secondly, the average hourly PET difference between two LCZs $x$ and $y$ at time $i$ $(\triangle \overline{P E T} x-y, i)$ was calculated according to $(\triangle \overline{P E T} x-y, i=$ PET $x, i-$ PET $y, i)$.

Thirdly, paired Student's $t$-tests were conducted to identify significant $(p<0.05)$ differences in PET between individual LCZs.

\section{Results}

Thermal comfort conditions in different LCZs of the city and its surroundings are analyzed based on the average hourly PET during the HW period. PET magnitude is used to express thermal comfort differences between defined LCZ classes ( $\left.\triangle \mathrm{PET}_{\text {LCZ X-Y }}\right)$.

At daytime, LCZs 5, D and 3 show particularly high thermal loads (Figure 3). Conversely, areas with substantial shading effect (e.g. LCZs $A$ and 2) have lower thermal load levels. The afternoon delayed reach of maximum PET value in LCZ 2 and decline and rise of PET in the LCZ $A$ is due to the shading effects of buildings and trees in the vicinity of the stations. At night, the highest PET values are in the 'street canyon' of the LCZ 2, whereas all other LCZs, especially the land cover LCZs $A$ and $D$ shows a deviation below the comfort range. In general, LCZ 5 had the highest average PET $\left(28.0{ }^{\circ} \mathrm{C}\right)$ during $\mathrm{HW}$, while LCZ $A$ had the lowest PET $\left(23.8^{\circ} \mathrm{C}\right)$.

In order to quantify relative differences in diurnal thermal comfort conditions between urban and non-urban areas, we have compared average hourly PET in each selected LCZ with average hourly PET values in LCZ $\mathrm{D}$ (low plants) during HW ( $\left.\triangle \mathrm{PET}_{\mathrm{LCZX} \mathrm{D}}\right)$. Figure 4 shows that all LCZs (except LCZ $A$ ) has higher PET values compared to LCZ $D$ from 17:00 UTC to 5:00 UTC. Maximum PET difference of $7.1{ }^{\circ} \mathrm{C}$ is noticed between LCZs 2 and $D$ at 0:00 UTC. These results agree with the literature which states that largest thermal contrasts occur during calm and clear nights. Contrary to this, LCZ D have higher PET values compared to majority of LCZs in the period 7:00-16:00 UTC with maximum difference of $8.5^{\circ} \mathrm{C}$ compared to LCZ A at 9:00 UTC.

When comparing average hourly PET between LCZs ( $\left.\triangle \mathrm{PET}_{\mathrm{LCZX-Y}}\right)$ (intra-urban analy- 


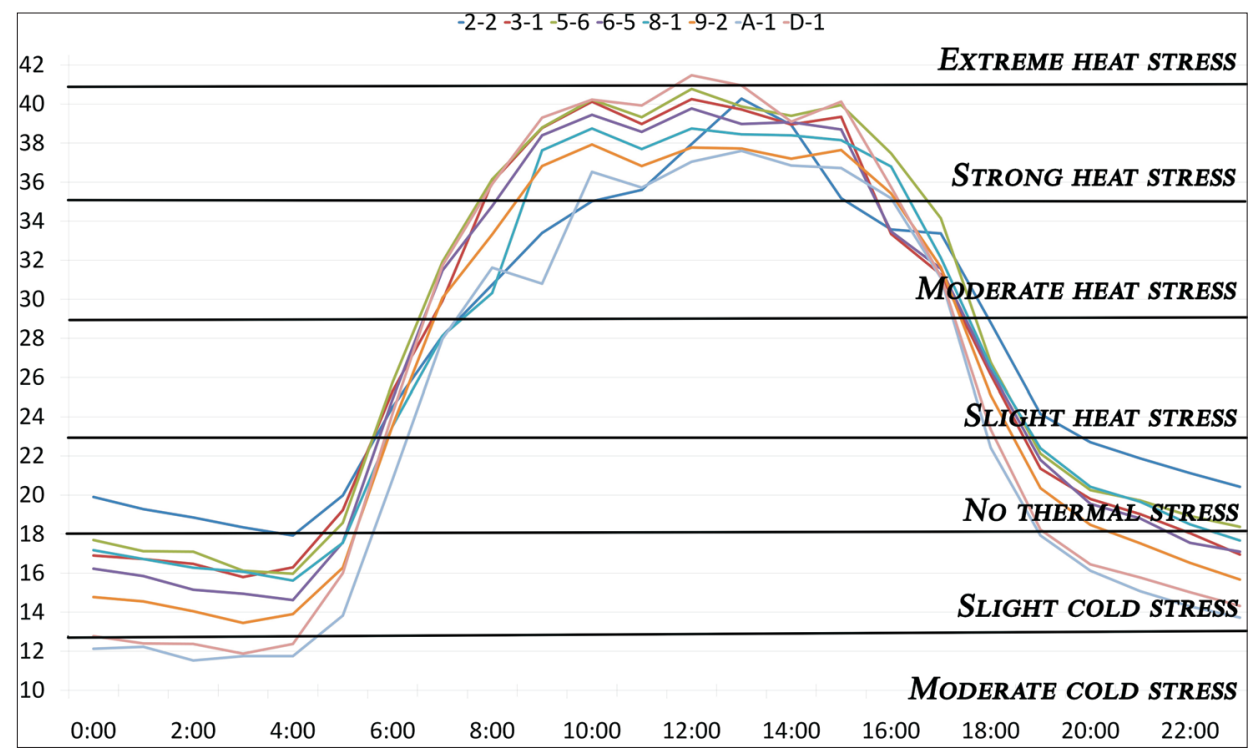

Fig. 3. Average hourly PET at measurements sites of the urban climate monitoring network in Novi Sad during HW (from $5^{\text {th }}$ to $8^{\text {th }}$ July 2014)

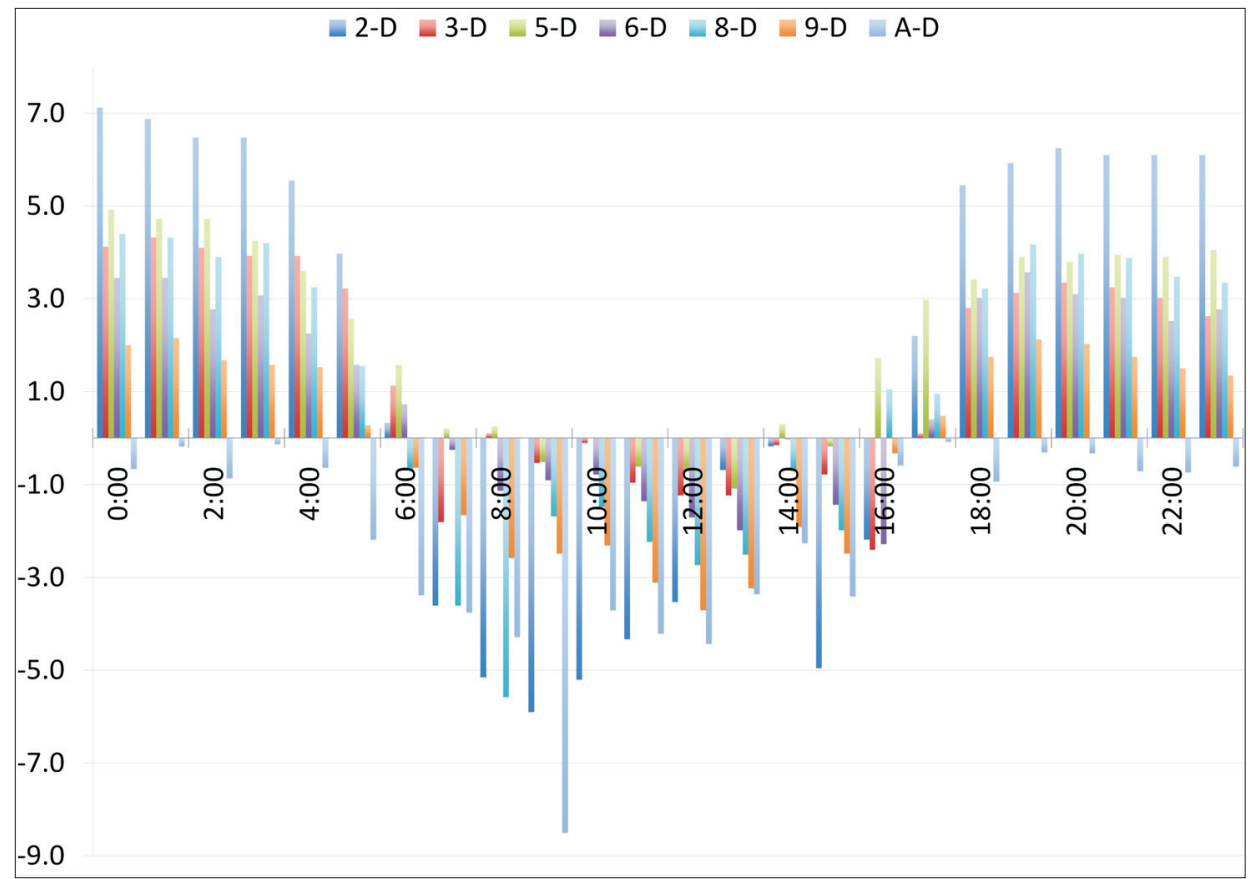

Fig. 4. Hourly PET magnitude $\left(\triangle \mathrm{PET}_{\text {LCZ X-D }}\right)$ in Novi Sad during HW (from $5^{\text {th }}$ to $8^{\text {th }}$ July 2014) 
sis) during HW, obtained differences can suggest similarity or contrasts of their thermal environment. Statistically significant thermal comfort differences occur between all LCZs except LCZs 6 and $8\left(0.1^{\circ} \mathrm{C}\right), 2$ and 3 , as well as $D$ and $9\left(0.2^{\circ} \mathrm{C}\right)$. This is presumably a consequence of similar values of surface structure (e.g. height and spacing of buildings and trees), cover (e.g. pervious or impervious) and fabric properties (e.g. albedo) between these LCZ pairs that lead to the creation of similar thermal comfort sensations inside them. Contrary to this, large differences in surface structure and cover properties essentially drive largest PET differences between built LCZs $(5,2$ and 3$)$ and natural LCZ $A\left(4.2{ }^{\circ} \mathrm{C}\right.$, $3.7^{\circ} \mathrm{C}$ and $3.5^{\circ} \mathrm{C}$, respectively). In general, highest thermal load is obtained in midrise, followed by low-rise, sparsely built, low plants and dense trees LCZs (Table 2).

At daytime, the LCZs do not show characteristic thermal comfort regimes with sig- nificant PET differences occurring between morphologically dissimilar LCZs (e.g. LCZs 2 and 9,3 and $D$ ). The most intense physiological stress is calculated for LCZ 5 while the least intense is calculated for LCZ A. This can be explained by more solar radiation reaching the open midrise areas of the city leading to more heating during the day in contrast to the dense trees zone. During the night the highest PET values are in LCZ 2 while the lowest are in LCZ A. This could be the effect of trapping of long-wave radiation inside the 'street canyon' of compact midrise zone. Thermal comfort differences between all LCZs are statistically significant during the night-time and more pronounced (up to $6.9^{\circ} \mathrm{C}$ ) than at daytime (up to $3.9^{\circ} \mathrm{C}$ ). This suggests that each LCZ has characteristic thermal comfort regime during the nighttime. The largest PET differences are between urban LCZ 2 and non-urban LCZs $D$ and $A$ $\left(6.9^{\circ} \mathrm{C}\right.$ and $6.4^{\circ} \mathrm{C}$, respectively) (Table 3$)$.

Table 2. PET magnitude* in Novi Sad during HW (from 5 to 8 July 2014)**

\begin{tabular}{c|c|c|c|c|c|c|c|cc}
\hline Station & $2-1$ & $3-2$ & $5-6$ & $6-5$ & $8-1$ & $9-2$ & A-1 & D-1 \\
\hline $2-1$ & - & -0.2 & 0.5 & -0.6 & -0.7 & -1.8 & -3.7 & -1.6 \\
$3-2$ & 0.2 & - & 0.7 & -0.4 & -0.5 & -1.6 & -3.5 & -1.4 \\
$5-6$ & -0.5 & -0.7 & - & -1.2 & -1.2 & -2.3 & -4.2 & -2.2 \\
$6-5$ & 0.6 & 0.4 & 1.2 & - & -0.1 & -1.2 & -3.1 & -1.0 \\
$8-1$ & 0.7 & 0.5 & 1.2 & 0.1 & - & -1.2 & -3.0 & -0.9 & -1 \\
$9-2$ & 1.8 & 1.6 & 2.3 & 1.2 & 1.1 & - & -1.9 & 0.2 \\
A-1 & 3.7 & 3.5 & 4.2 & 3.1 & 3.0 & 1.9 & - & 2.1 \\
D-1 & 1.6 & 1.4 & 2.2 & 1.0 & 0.9 & -0.2 & -2.1 & - \\
\hline
\end{tabular}

${ }^{*} \triangle \mathrm{PET}_{\mathrm{LCZ} \mathrm{X}_{-} \mathrm{F}} \cdot{ }^{* *}$ Differences are presented as the LCZ type in column minus the LCZ type in row. Italics: statistically significant PET differences at the $5 \%$ level (paired t-test). Normal: statistically insignificant PET differences at the $5 \%$ level (paired t-test)

Table 3. PET magnitudes for day-time* and night-time** in Novi Sad during HW from $5^{\text {th }}$ to $8^{\text {th }}$ July 2014.

\begin{tabular}{c|c|c|c|c|c|c|c|c}
\hline Station & $2-1$ & $3-2$ & $5-6$ & $6-5$ & $8-1$ & $9-2$ & A-1 & D-1 \\
\hline $2-1$ & - & 2.9 & 2.2 & 3.3 & 2.4 & 4.6 & 6.9 & 6.4 \\
$3-2$ & -1.4 & - & -0.7 & 0.5 & -0.4 & 1.7 & 4.1 & 3.5 \\
$5-6$ & -2.1 & -0.8 & - & 1.2 & 0.3 & 2.5 & 4.8 & 4.3 \\
$6-5$ & -1.0 & 0.4 & 1.2 & - & -0.9 & 1.3 & 3.6 & 3.1 \\
$8-1$ & -0.3 & 1.0 & 1.8 & 0.6 & - & 2.2 & 4.5 & 4.0 \\
$9-2$ & 0.1 & 1.5 & 2.3 & 1.1 & 0.5 & - & 2.3 & 1.8 \\
A-1 & 1.8 & 3.2 & 3.9 & 2.8 & 2.2 & 1.7 & - & -0.5 \\
D-1 & -1.2 & 0.1 & 0.9 & -0.3 & -0.9 & -1.4 & -3.0 & - \\
\hline
\end{tabular}

*Bottom left area. Differences are presented as the LCZ type in column minus the LCZ type in row. **Upper right area. Differences are presented as the LCZ type in row minus the LCZ type in column; Italics: statistically significant PET differences at the 5\% level (paired t-test). Normal: statistically insignificant PET differences at the $5 \%$ level (paired t-test). 


\section{Discussion and conclusions}

Outdoor human thermal comfort conditions were evaluated in different LCZs of the city of Novi Sad during a HW period. The data originated from the UCMS developed in Novi Sad. The highest average PET was noticed in built up LCZs 5 and 2, while the lowest were in areas with a substantial pervious land cover, namely the LCZs $A, 9$ and $D$. The results showed that statistically significant thermal comfort differences exist between the majorities of the LCZs. Only between LCZs 2 and 3, 6 and 8 as well as 9 and $D$ this was not the case. Reasons for this could be the similar values of surface structure, cover and fabric properties (e.g. albedo) between these LCZ pairs.

During the daytime hours, the smallest thermal comfort differences occurred between LCZs with substantially different structural, cover, fabric and metabolism properties (i.e. between compact midrise and sparsely built LCZs) suggesting that LCZs do not have unique thermal environment at that time. Contrary to this, during the night all LCZs are thermally unique and exhibit statistically significant PET differences. Highest PET values were observed in midrise zones, followed by low-rise and sparsely built zones and lastly by low plants and dense trees zones. Furthermore, higher PET values were observed in compact zones when compared to open zones.

Research of human bio-climatologic comfort sensation in different LCZs is still scarce. This is no surprise as LCZ scheme is mainly introduced as a concept to enhance the understanding of air temperature differences within the urban area. Nevertheless this scheme can be used to observe the values of thermal comfort indices in different areas of cities. Previous studies regarding thermal comfort in Novi Sad showed PET differences up to $1.6^{\circ} \mathrm{C}$ between subsequent LCZs and up to $5.1^{\circ} \mathrm{C}$ for dissimilar LCZs on tropical day. On cold freezing day, PET differences were larger with up to $2.0^{\circ} \mathrm{C}$ between close LCZs and up to $6.3^{\circ} \mathrm{C}$ between dissimilar
LCZs (MiLošEvić, D.D. et al. 2015a). Results of our study are in accordance with findings of Kovács, A. and Németh, Á (2012) who found that LCZ 2 of Budapest has average PET values higher by $3{ }^{\circ} \mathrm{C}$ when compared to the suburbs (between LCZs 6 and $A$ ). The lower PET values during the daytime in residential area of the city correspond with the findings of Puliafito, S.E. et al. (2013) who point out that residential areas in Mendoza (Argentina) had from $2.0^{\circ} \mathrm{C}$ to $4.0^{\circ} \mathrm{C}$ lower PET values than the periphery of the city during the summer afternoon. In accordance with our results, higher thermal loads (i.e. PET values) were obtained for built LCZs 2 and 5 in Oberhausen (Germany) during the hot days $\left(\mathrm{Ta}_{\max }>30^{\circ} \mathrm{C}\right)$ when compared to LCZs 9 and $A$ (Muller, N. et al. 2014).

Numerous UHI studies used LCZ scheme to assess Ta differences in urban areas. Results from these studies showed that $\mathrm{Ta}$ during summer nights in LCZs with high impervious/building coverage in Berlin (FenNer, D. et al. 2014), Szeged (Lelovics, E. et al. 2016), Nancy (Leconte, F. et al. 2015) and Dublin (Alexander, P.J. and Mills, G. 2014) were higher up to $6.0^{\circ} \mathrm{C}, 5.2{ }^{\circ} \mathrm{C}, 4.4{ }^{\circ} \mathrm{C}$ and $4.2{ }^{\circ} \mathrm{C}$ than $\mathrm{Ta}$ in $\mathrm{LCZs}$ with high pervious/vegetated coverage in these cities, respectively. This is in accordance with our results as nocturnal PET values in built LCZs of Novi Sad were up to $6.9^{\circ} \mathrm{C}$ higher than in land cover LCZs which is not a surprise as $\mathrm{Ta}$ is part of the PET calculation.

The urban climate monitoring network in Novi Sad based on LCZ scheme showed to be suitable for the intra-urban thermal comfort research during the HW period. Comfortable and uncomfortable outdoor areas in the cities were detected and thermal comfort differences were quantified. Nevertheless, further long-term UHI and thermal comfort investigations from different cities are needed in order to evaluate and improve the proposed LCZ scheme. Measurements of meteorological elements from UCMSs based on LCZ scheme will help in achieving this goal. Furthermore, measured and calculated parameters of human thermal comfort from 
UCMSs will provide urban planners and architects the opportunity to propose and design comfortable areas in the city in order to mitigate the negative effects of urban climate.

Acknowledgement: The study was supported by the Hungary-Serbia IPA Cross-border Co-operation EU Programme (HUSRB/1203/122/166 - URBAN-PATH) and the Serbian Ministry of Education, Science and Technological Development (project no. 43002).

\section{REFERENCES}

Alexander, P.J. and Mills, G. 2014. Local climate classification and Dublin's urban heat island. Atmosphere 5. 755-774.

Bajšanski, I.V., MilošEvić, D.D. and Savić, S.M. 2015. Evaluation and improvement of outdoor thermal comfort in urban areas on extreme temperature days: Applications of automatic algorithms. Building and Environment 94. 632-643.

Christensen, J., Hewitson, B., Busuioc, A., Chen, A., GAO, X. and HeLD, I. 2007. Regional climate projection. Technical report. In Climate Change 2007: The Physical Science Basis. Contribution of Working Group I to the fourth assessment report of the Intergovernmental Panel on Climate Change. Eds.: Solomon, S., QIn, D., Manning, M., Chen, Z., Marquis, M. and Averyt, K.B. Cambridge UK and New York, Cambridge University Press.

EMC 2003. The GFS Atmospheric Model. NCEP Office Note 442, 14 p.

Emmanuel, R. and KRÜGER, E. 2012. Urban heat island and its impact on climate change resilience in a shrinking city: The case of Glasgow, UK. Building and Environment 53. 137-149.

Fenner, D., Meier, F., Scherer, A. and Polze, A. 2014. Spatial and temporal air temperature variability in Berlin, Germany, during the years 2001-2010. Urban Climate 10. 308-331.

GÁL, T. and Unger, J. 2009. Detection of ventilation paths using high-resolution roughness parameter mapping in a large urban area. Building and Environment 44. 198-206.

Kottek, M., Grieser, J., Beck, C., Rudolf, B. and Rubel, F. 2006. World map of the Köppen-Geiger climate classification updated. Meteorologische Zeitschrift 15. 259-263.

Kovács, A. and Németh, Á. 2012. Tendencies and differences in human thermal comfort in distinct urban areas in Budapest, Hungary. Acta Climatologica et Chorologica 46. 115-124.

Leconte, F., Bouyer, J., Claverie, R. and Petrissans, M. 2015. Using Local Climate Zone scheme for
UHI assessment: Evaluation of the method using mobile measurements. Building and Environment 83. 39-49.

Lehnert, M., Geletič, J., Husák, J. and Vysoudil, M. 2014. Urban field classification by "local climate zones" in a medium-sized Central European city: the case of Olomouc (Czech Republic). Theoretical and Applied Climatology 122. 531-541.

Lelovics, E., Unger, J., GÁl, T. and GÁl, C.V. 2014. Design of an urban monitoring network based on Local Climate Zone mapping and temperature pattern modeling. Climate Research 60. 51-62.

Lelovics, E., Unger, J., SAvić, S., GÁL, T., MilošEvić, D., Gulyás, Á., Marković, V., Arsenović, D. and GÁL, CV. 2016. Intra-urban temperature observations in two Central European cities: a summer study. Időjárás (in print)

Matzarakis, A. and Mayer, H. 1996. Another kind of environmental stress: thermal stress. In WHO Collaborating Centre for Air Quality Management and Air Pollution Control 18. 7-10.

Matzrakis, A., Rutz, F. and Mayer, H. 2007. Modelling radiation fluxes in simple and complex environments: application of the RayMan model. International Journal of Biometeorology 51. 323-334.

Michalakes, J., Dudhia, J, Gill, D., Henderson, T., Klemp, J., Skamarock, W. and Wang, W. 2004. The Weather Reseach and Forecast Model: Software architecture and performance. Proceedings of the $11^{\text {th }}$ ECMWF Workshop on the Use of High Performance Computing In Meteorology, Reading, UK.

Milošević, D.D., Savić, S.M., Unger, J. and Gál, T. 2015a. Urban climate monitoring system suitability for intra-urban thermal comfort observations in Novi Sad (Serbia) - with 2014 examples. $9^{\text {th }}$ International Conference on Urban Climate jointly with $12^{\text {th }}$ Symposium on the Urban Environment. Toulouse, France, 1-6.

MiLošEvić, D.D. and SAvić, S.M. 2015b. Thermal comfort observations in the City of Novi Sad (Serbia) in 2014. EUGEO 2015 - Convergences and Divergences of Geography in Europe, Budapest, p. 78.

Muller, N., Kuttler, W. and Barlag, A.-B. 2014 Counteracting urban climate change: adaptation measures and their effect on thermal comfort. Theoretical and Applied Climatology 115. 243-257.

Ndetto, L.E. and Matzarakis, A. 2015. Urban atmospheric environment and human biometeorological studies in Dar es Salaam, Tanzania. Air Quality, Atmosphere and Health 8. 175-191.

Puliafito, S., Bochaca, F., Allende, D. and Fernandez, R. 2013. Green areas and microscale thermal comfort in arid environments: A case study in Mendoza, Argentina. Atmospheric and Climate Sciences 3. 372-384.

SAVić, S., BajšAnski, I. and MilošEvić, D.D. 2015. Evaluation of outdoor thermal comfort in urban transformations of Novi Sad (Serbia). EUGEO 2015 
- Convergences and Divergences of Geography in Europe, Budapest, p. 79.

Savić, S., Milošević, D., Lazić, L., Marković, V., Arsenović, D. and Pavić, D. 2013. Classifying urban meteorological stations sites by "Local Climate Zones": Preliminary results for the City of Novi Sad (Serbia). Geographica Pannonica 17. (3): 60-68.

Šećerov, I., SAVić, S., MilošEvić, D., Marković, V. and BAJŠANSKI, I. 2015. Development of an automated urban climate monitoring system in Novi Sad (Serbia). Geographica Pannonica 19. (4): 174-183.

SiU, L.W. and HART, M.A. 2013. Quantifying urban heat island intensity in Hong Kong SAR, China. Environmental Monitoring and Assessment 185. 4383-4398.

SteWART, I.D. and OKe, T.R. 2012. Local Climate Zones for urban temperature studies. Bulletin of American Meteorological Society 93. 1879-1900.

Stewart, I.D., OKe, T.R. and Krayenhoff, E.S. 2014. Evaluation of the "local climate zone" scheme using temperature observations and model simulations. International Journal of Climatology 34. 1062-1080.
Thomas, G., Sherin, A.P., Ansar, S. and Zachariah, E.J. 2014. Analysis of urban heat island in Kochi, India, using a modified local climate zone classification. Procedia Environmental Sciences 21. 3-13.

Unger, J., SAVIĆ, S. and GÁL, T. 2011. Modelling of the annual mean urban heat island pattern for planning of representative urban climate station network. Advances in Meteorology 2011. ID 398613, 9 p.

Unger, J., SAVic, S., Gál, T. and Milošević, D. 2014. Urban climate and monitoring network system in Central European cities. Novi Sad, 103 p.

Unger, J., SAvić, S., GÁl, T., MilošEvić, D., Marković, V., Gulyás, Á. and Arsenović, D. 2015. Urban climate monitoring networks based on LCZ concept. $9^{\text {th }}$ International Conference on Urban Climate jointly with $12^{\text {th }}$ Symposium on the Urban Environment, Toulouse, France, 1-6.

Villadiego, K. and Velay-Dabat, M.A. 2014. Outdoor thermal comfort in a hot and humid climate of Colombia: A field study in Barranquilla. Building and Environment 75. 142-152. 


\title{
AQUINCUM Ancient landscape - ancient town
}

\author{
Edited by \\ Katalin H. Kérdô and Ferenc Schweitzer \\ Geographical Institute Research Centre for Astronomy and Earth Sciences MTA
}

Budapest, 2014. 188 p.

Geomorphological-paleoenvironmental studies supporting archeological excavations and investigations are to be considered a new trend within the broader sphere of studies on environment and geomorphology. By publishing the latest achievements of researches of this kind carried out on the territory of Aquincum and in its wider surroundings this book may equally reckon on the interest of professional circles and inquiring audience.

Therefore the publication of such a volume of somewhat unusual character is welcome. The project could be completed as a result of the close cooperation of two important branches of studies, notably geography and archeology. They both have long lasting traditions in our country and on this occasion were represented by two prominent institutions, the Geographical Institute of the Hungarian Academy of Sciences, and the Aquincum Museum of the Budapest History Museum. Their contribution has made possible the publication of this book.

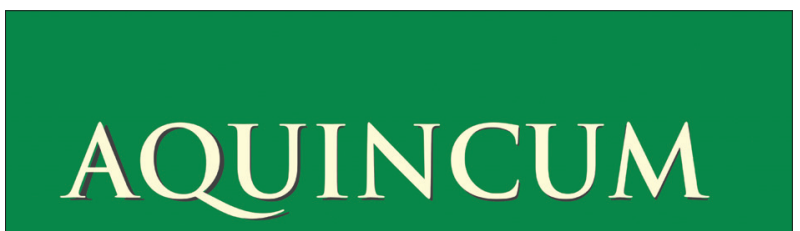

Ancient landscape - ancient town

Edited by:

Katalin H. Kérdő - Ferenc Schweitzer

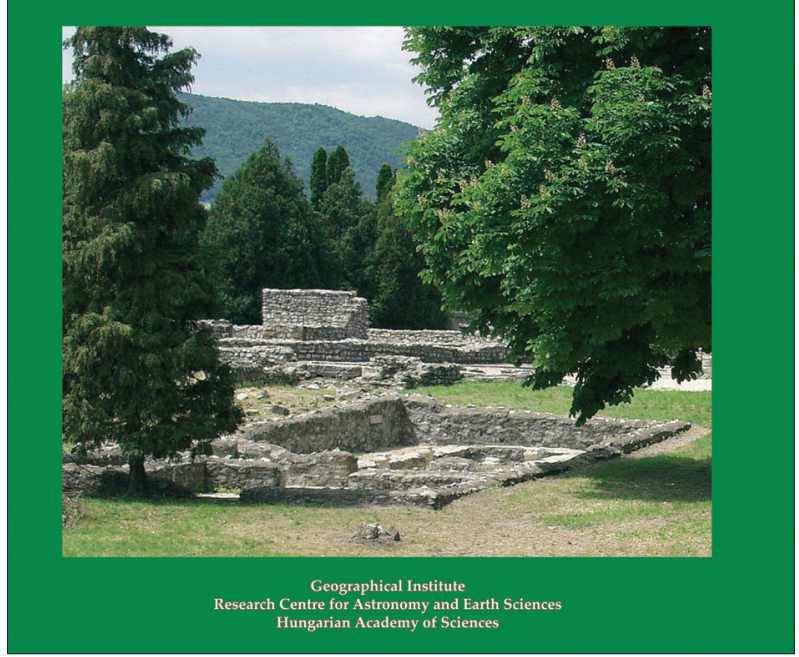

The studies were aimed to clear up the role of those natural factors which exerted a profound influence on the development of the settlement structure during the Roman Period. Romans had a special ability to realize advantages provided by geomorphological characteristics and they had made a good use of natural waters, flood-plain surface features and parent rocks for their creativity.

The volume is also deemed as a pioneering work with regard to the richly illustrated presentation of geological, geographical and other natural features exposed in several places in the course of archeological excavations. A short summary shows the most important objects of the Roman Period related to natural endowments and traces of activities of the time leading to environmental transformation.

Based on geomorphological evidence a new answer is proposed to a previously raised problem whether the Hajógyári Island existed as an islet already in the time of the Romans. Another intriguing issue tackled is the purpose of the system of trenches found in several places along the Danube River.

Price: EUR 20.00

Order: Geographical Institute of RCAES MTA. H-1112 Budapest, Budaörsi u. 44. E-mail: magyar.arpad@csfk.mta.hu 